\title{
CONNECTED TVS AND INTERACTIVITY
}

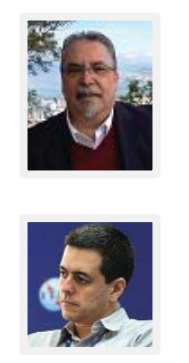

\section{Moderator: André Barbosa Filho}

Chefe de Assessoria da Diretoria da Presidência da EBC / SET

Broadcast and Broadband Integration System

Speaker: Marcelo Moreno

DR. Professor at the UFJF and Rapporteur of the IBB/ITU project: Integrated Broadcast-Broadband (IBB) - International Telecommunication Union (ITU)

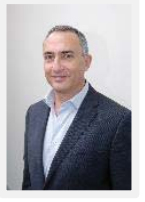

Research and Development: incentives for and challenges to interactivity

Speaker: Marco Szili

Founder \& CEO / TELE System

\section{Communication and Digital Interaction on TV}

Speaker: Cosette Espindola De Castro

Profa. Dra. no Programa de Pós-Graduação em Comunicação na Universidade Católica de Brasília (UCB)

\section{Connection and Telecommunication on Television}

Speaker: Luiz Eduardo Cunha Leite

Chief Security Officer (CSO) / MOPA Embedded Systems 


\section{Consumo}

\section{CONNECTED TVS AND INTERACTIVITY}

\section{Moderador: ANDRÉ BARBOSA FILHO}

Chefe de Assessoria da Diretoria da Presidência da EBC / SET

A interatividade, seja como tecnologia bidirecional voltada para o uso universal de serviços públicos seja para a informação, educação, cultura e entretenimento passou a ser, apos a disseminação da Rede Mundial, preponderante em todas as plataformas de dados e aplicativos audiovisuais.

A radiodifusão, por sua vez ao se tornar digital surge como base integradora destes recursos interativos prometendo ampliar o acesso digital a bilhões de pessoas no mundo sem conexão domiciliar.

Este é o tema de nossa discussão na mesa que percorre o mundo audiovisual conectado a oferta digital de aplicativos audiovisuais interativos pela TV Digital.

\section{- Broadcast and Broadband Integration System} Speaker: Marcelo Moreno

DR. Professor at the UFJF and Rapporteur of the IBB/ITU project: Integrated Broadcast-Broadband (IBB) - International Telecommunication Union (ITU)

- Research and Development: incentives for and challenges to interactivity Speaker: Rosilda Prates

Diretora Executiva P\&D Brasil - Ass Ind de Desenvolvimento Tecnológico Nacional / Intelbras, Parks S/A Comunicações Digitais, Datacom

- Communication and Digital Interaction on TV Speaker: Cosette Espindola De Castro

Profa. Dra. no Programa de Pós-Graduação em Comunicação na Universidade Católica de Brasília (UCB)

- Connection and Telecommunication on Television

Speaker: Luiz Eduardo Cunha Leite

Chief Security Officer (CSO) / MOPA Embedded Systems

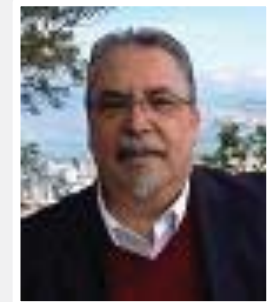

ANDRÉ BARBOSA FILHO - SET

$\mathrm{PhD}$ in Communication Sciences and researcher in digital media - SET.

$\mathrm{PhD}$ in Communication Sciences and researcher in digital media and communication strategies.

Studies the development of public policies in the digital communication field

Specializations: Digital TV, Digital Radio, broadcasting network structures, public policy management and industrial strategies. 

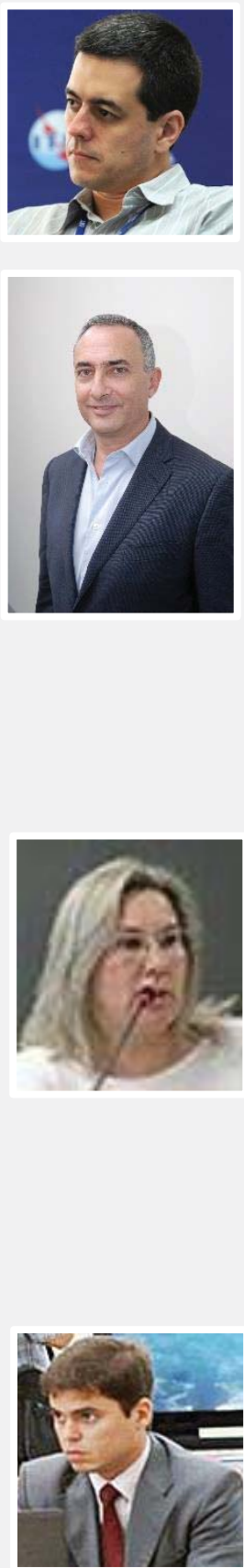

\section{LUIZ EDUARDO CUNHA LEITE}

Chief Security Officer (CSO) - MOPA Embedded Systems

Luiz Eduardo Cunha Leite - MOPA Embedded Systems, is a Computer Engineer, with a Master's in Computer Sciences and a Doctorate in Software Engineering. While a researcher at the Federal University of Rio Grande do Norte, he supervised the development of the middleware system for the project entitled the Brazilian Digital TV System, coordinated by the CPQd. Founding partner of MOPA Embedded Systems, he is currently the company's CSO. 